\title{
Peyzaj Uygulamalarında Sık Kullanılan 4 Farklı Serin İklim Çim Tohumunun Farklı Ortamlarda Gösterdikleri Performansların Belirlenmesi
}

\author{
Yavuz ALKAN ${ }^{1 *}$, Alper SAĞLIK ${ }^{2}$, Abdullah KELKİT ${ }^{2}$, Engin GÜR ${ }^{1}$, Elif SAĞLIK ${ }^{1}$ \\ ${ }^{1}$ Çanakkale Onsekiz Mart Üniversitesi Lapseki Meslek Yüksekokulu, Çanakkale / Türkiye \\ ${ }^{2}$ Çanakkale Onsekiz Mart Üniversitesi, Mimarlık ve Tasarım Fakültesi, Çanakkale / Türkiye
}

\section{Öz}

Çalışmada, Çanakkale kentseli çim alan tesisinde ağırlıklı kullanılan çim tohumlarından Lolium perenne Topgun (İngiliz Çimi), Festuca rubra Red Skın (Kırmızı Yumak) ve Poa pratensis Avalanche (Çayır Salkım Otu) her birinin kum, mil, bahçe toprağı ve her üçünün eşit karışımından oluşan 4 farklı yetiştirme tavasındaki çimlenme performanslarının belirlenmesi amaçlanmıştır. Kaplama hız ve oranları ile renk ve dokudan oluşan performansları çok $a z, a z$, fazla ve çok fazla dereceleri kapsamında belirlenerek en uygun ortam/ortamlar tespit edilmiştir. Her çim tohumu için 4 tekerrürlü yapılan bu çalışmada tava başına ortalama ölçüm değerleri alınarak en uygun ortamın tespitine gidilmiştir. Sonuç olarak, her üç çim türüne ait tohum çeşitlerinin sırasıyla eşit karışım, mil, ve bahçe toprağının yer aldığı tavalarda en iyi performansı gösterdikleri tespit edilmiştir. Bu tespitleri teyit etmek için ortalama ölçüm değerlerine uygulanan Post-Hoc Testi sonucunda 1. derecede "eşit karışım", 2. derecede ise, "mil" lehine anlamlı fark olduğu ortaya çıkmıştır. Ayrıca, varyans analizine göre de, çim tohumlarının farklı yetiştirme ortamlarına gösterdikleri tepkimelerin 0,05 düzeyinde önemli olduğu tespit edilmiştir $(\mathrm{P}<0,05)$. Birbirini teyit eden bu sonuçlara göre de, Çanakkale kent insanının yaşam standartlarını yükselten çim alan tesisinde, çalışma kapsamında denemesi yapılan çim türlerine ait tohumların, kum, mil ve bahçe toprağından oluşan eşit oranlı kombinasyonda estetik ve işlevsel açıdan en iyi kullanım potansiyeline sahip olduğu ortaya çıkmıştır.

Anahtar Kelimeler: Çim Alan Tesisi, ÇimTohumu, Toprak Sınıfları, Çanakkale.

\section{Determination of The Performances of Four Different Cool Climate Grass Seeds Which are Frequently Used in Landscape Applications in Different Environments}

\begin{abstract}
In order to determine the optimum environments for grass germination Lolium perenne Topgun, Festuca rubra Red Skin and Poa pratensis Avalanche seeds, which are mostly used in grass field facilities within the urban area of Çanakkale, were planted into four different cultivation pans consisting of sand, shaft, garden soil and an equal mixture of all three types of soil for germination, the speed and rate, colour and texture and consequently their performance, were evaluated. The evaluation of their performance rates ranged from "very low (1)" to "very high (4)". In this study which was repeated four times for each grass seed, the most convenient environment was intended to be determined by considering the mean values of each cultivation pan. Moreover, Post-Hoc test was applied to these measurements for the verification. Seeds for each grass types showed the best performance in an equal mixture of the sand, shaft, and garden soil with the shaft, and garden soil respectively in the cultivation pans. In order to confirm these results Post-Hoc test was applied to analyse the results and according to the descriptive statistics, it showed that there existed a significant difference in favour of the 'equal mixture' for the first degree and in favour of 'shaft' for the second degree. According to variance analysis grass seeds in different growth environment showed significant reactions on the level of 0.05 According to results, grass field facility which increases life standards of people in Çanakkale, tested seeds of grass types within the context of this study aesthetically and functionally had the best potential of use in combination of equal, sand, shaft and garden soil.
\end{abstract}

Keywords: Grass Field Facility, Grass Seed, Soil Classes, Canakkale.

\footnotetext{
*Sorumlu Yazar (Corresponding Author):

Yavuz ALKAN (Dr.Öğr.Üyesi); Çanakkale Onsekiz Mart Üniversitesi, Lapseki

Meslek Yüksekokulu, Lapseki, 17800, Çanakkale, Türkiye. Tel: +90 (286) 522 6104,

Fax: +90 (286) 522 6101, E-mail: yalkanz58@gmail.com ORCHID: 0000-0003-

0137-0700

Geliş (Received) : 29.06.2019

Kabul (Accepted) : 27.09.2019

Basım (Published) : 15.12.2019
} 


\section{Giriş}

Yapılaşmanın giderek artması kentlerde yeşil alanların gün geçtikçe azalmasına yol açmıştır (Sağlık ve ark., 2016). Bu durum Çanakkale kentselini de etkisi altına almış, son yıllarda konut sektörünün orantısız artışını ve buna bağlı olarak da peyzaj alanlarının aynı şekilde azalışını ortaya çıkarmıştır (Alkan ve ark., 2016). Günümüzde hızlı ve plan dışı kentleşmeyle gelen önemli sorunlardan biri de yeşil alanlardaki artış hızının yapılaşmalardaki artış hızıyla eşdeğer nitelik ve nicelikte olmamasıdır (Alkan ve Uslu, 2016). Özellikle nüfus ve buna bağlı mimari yapılaşmaların hızla artması yüksek katlı ve sıkışık binalardan oluşan plansız bir kent dokusunu oluşturmakla birlikte, peyzaj kullanımlarını da rasyonellikten uzaklaştırmaktadır. Bu uzaklaşmaya bağlı olarak da doğal ve kültürel kaynaklar hızla tükenmektedir (Alkan ve Uzun, 2016). Öyle ki, peyzaj planlama ve tasarımlarının vazgeçilmez öğesi olan yeşil alanların yüzey kullanımını teşkil eden çim alan tesisleri de bundan olumsuz etkilenmektedir (URL-1). Bu haliyle plansız kentleşmeye bağlı olarak ortaya çıkan dış mekân sorunu, günümüz kent insanının yaşam kalitesinde etkisini oldukça yoğun hissettirmektedir (URL-1).

UNİCEF'in Türkiye geneline yönelik çalışmasında ağırlıklı olarak yeterli yeşil alan olmayışı, mevcut olanlarda da güvenlik olanaklarının zayıf olmasına bağlı olarak çocuk sorunlarının/suçlarının da arttığına dikkat çekilmiştir (URL-1; URL-2). Yeşil alanların sahip olduğu olanak ve donatılarla birlikte önemi bu noktada öne çıkmaktadır. Bu durum gerekli olanak ve donatıların olduğu yeşil alanların, nispeten bu donatılara bağlı olarak da çim alanların bir kent için önemini yadsınamaz kılmaktadır (URL-1). Çünkü, bu alanlar çocuk refahından başlayarak, tüm kentli insanların refahına varan bir kentsel yaşam kalitesinin önemli bir belirleyicisidir (Watschke ve Schmidt, 1992). Dolayısıyla Çanakkale kentselinde önemli bir sorun da yeşil alan sorunudur. Kentlinin yaşam kalitesinin (memnuniyetinin) bu standartlara bağlı olması da bu sorunu daha da önemli kılmaktadır (Sağlık ve ark., 2016). Bu durum kentsel doku formasyonunda yaşamak zorunluluğuna mahkûm olan bireyin de doğal/kültürel peyzaja olan özlemini gün geçtikçe artırmaktadır. Kent dokusunun bir parçası olan mimari yapılara kadar yeşil dokunun hâkim olmaya ve bu noktada yaygın bir kullanım arzetmeye başladığını da görmek bu açıdan dikkat çekicidir. Öyle ki, bu aşamada dikey bahçe/dikey orman gibi yapılarla bir bütünlük arzetmeye başlayan söz konusu mimari yapılar, yatay ya da yüzey peyzaj planlama ve tasarımlarında kütlesel yapı çevrelerinin çim alanı tesisi ile birlikte ele alınmasını zorunlu kılmıştır. Bu kapsamda kent içinde yeşil alan azlığına kentsel peyzaj tasarımı projelerinde çözüm aranmaya başlanmıştır (Sağlık ve ark., 2016). Böylece kentte niceliği ve niteliği artacak olan açık ve yeşil alanlar, betonlaşmanın olumsuz etkisini azaltan, kentlinin doğaya özlemini gideren ve kentlinin yaşam kalitesini artıran mekanlar olabilecektir (Sağlık ve ark., 2016). Bu da göstermektedir ki, gelecek kentlerinin daha yaşanabilir kılınması, yeşil alan düzenlemeleri ile mümkün olabilecektir. Buradan da çim alanlar kentsel yeşil dokunun önemli bir bölümünü kapsaması yönünden öne çıkmaktadır. Çim alan tesisinde öne çıkan başlıca unsur bölgenin ekolojik faktörlerine uygun nitelikte çim tohumu kombinasyonlarının seçilmesidir. Diğer bir unsur ise, verimli ve uzun süreli kullanışlılığı sağlaması adına en uygun yetiştirme ortamının hazırlanmasıdır. Bunun yanısıra, iyi bir sulama, gübreleme ve biçim programının uygulanması ile de kentsel alanda fonksiyonel ve estetik açıdan kültürel peyzaj değerinin artması da sağlanmış olabilecektir (Küçükerbaş ve ark., 1997; Demirel ve ark. 2006). Çanakkale gibi Karasal ve Akdeniz iklim tiplerini birlikte içeren bölgeler açısından çim alan tesisinde çoklu çim tohumu karışımının (İngiliz Çimi, Kırmızı Yumak ve Çayır Salkım Otu) tercih edilmesi, yayılma hızı ve tekstür açısından daha başarılı çim alanı tesisini beraberinde getirecektir. Karışım çimleri gerek alana yaygın görsellik kazandırması, gerekse de hastalık ve zararlıya bağlı olarak oluşabilecek tek çim türü kaynaklı açıklıkları diğer çim türlerinin kapatabilmesi özelliği nedeniyle tercih edilebilmektedir. Bu yönüyle alanda çimin canlı ve yeşil olan yaygın görünüşü devamlılık arz edecektir (Watschke ve Schmitd, 1992). Söz konusu canlı ve yeşil görünümün her sezon kendini koruması, yine çim karışımına her mevsime dönük türlerin katılımıyla mümkün olabilmektedir. Zira her mevsimin çevresel şartları farklı çim türlerini karışımda bulundurmayı gerektirmektedir (Arslan, 2010; Alagöz ve Türk, 2017). Sonuç olarak yıl boyu alanda/yüzeyde canlı ve yeşil doku olarak kalabilen bir çim alanı tesis edilebilecek olması, kent insanı için de tüm yıl söz konusu peyzaj donatısından yararlanması anlamına gelecektir. Çanakkale kentsel dokusunda aktif yeşil alan planlama ve tasarımlarında önemli bir yeri olan çim alanlarında bölge ekolojisine uygun çim türlerinin (İngiliz Çimi, Kırmızı Yumak ve Çayır Salkım Otu) farklı ortamlarda (kum, mil, bahçe toprağı ve eşit karışım) gösterdikleri performanslar üzerine bir araştırma bulunmamaktadır. Karışımda yer alan çim türlerinin performanslarında belirleyici olan ortamların tespiti ile daha nitelikli, dayanıklı ve sık dokulu çim alanların tesisi mümkün olabilecektir. Çalışmanın bu kapsamda söz konusu eksiği gidermek adına peyzaja önemli bir katkı sağalayacağı planlanmaktadır. Dolayısıyla, yeterli nitelik ve nicelikte çim alanların planlama ve tasarımlarında bu çalışma verileri sayesinde ulaşılan sonuçlar ışı̆̆ında elde edilen çim türlerine ve uygun yetiştirme ortamlarına yer verilmesi çözüm odaklı önemli bir adımı oluşturacaktır. 


\subsection{Kuramsal Çerçeve}

Farklı kaynaklarda "açık ve yeşil alan" kavramlarına getirilen tanımlara bakıldığında, Sağlık ve ark., (2016), öncelikle, kent insanının refahını artıran, doğaya olan hasretini nispeten gideren ve mimari yapılaşmanın negatif etkisini azaltan alanlar olarak tanımlamaktadır. Diğer bir kavram olarak "açık alan" kavramı ise, mimari yapı ve araç trafiğine ait yollar dışında kalan, aynı zamanda kentsel dokuda da önemli bir yere sahip olan açık/boş alanlar şeklinde ifade edilmektedir (Özbilen, 1991). Diğer taraftan konutlaşmanın olmadığı, rekreasyonel kullanım potansiyeli olan dış mekanlara açık alan denmektedir. Buna, bitkilendirilmesi az ya da hiç olmayan su kaplı yüzeylere sahip meydanlar da dahil edilebilmektedir (Gül ve Küçük, 2001). Mahalle parkı, çocuk bahçesi, spor alanları, piknik alanları, rekreaktif alanlar, anakent ölçeğinde fuar, botanik bahçesi, hayvanat bahçesi ile bölge parkları da dahil olmak üzere insan yaşamına rahatlık veren alanlara da "yeşil alan" denmektedir (URL3). "Açık ve yeşil alan" ise, toplumun sosyal, kültürel ve rekreatif ihtiyaçlarının karşılanması ile yaşam kalitelerini artıran özel ve kamu sektörlerince inşa edilen dini, kültürel, sosyal tesisler, açı/kapalı spor tesisleri ile çocuk oyun alanı, park ve rekreasyon alanı gibi sosyal alt yapı alanlarıdır (URL-4). Diğer taraftan çim alanları, sık gelişen, eş dağılımlı bir yayılım gösteren, biçmeyle tıraşlanabilen Poaceae familyası kapsamındaki bitki topluluklarının kullanılarak kültürel uygulamalarla oluşturulmuş yeşil alanlar olarak tanımlanmaktadır (Orçun, 1969). Çim alan tesisinde karışım halinde çimlerin kullanılması üzerine gelişmiş ülkelerde pek çok araştırma yapılmış olup, talebe göre çim alanı tesis edilebilecek karışımların en az iki ve daha çok türden oluşturulması gerekmektedir (Alagöz ve Türk, 2017). Sağlıklı çözümler getirmek adına gerek doğal gerekse kültürel peyzaja estetik ve fonksiyonel katkılar sunan çim alanlar, kentsel ve kırsal dokunun vazgeçilmez donatılarıdır. Kullanım alanlarına ve özelliklerine bağlı olarak çim alanlarının temelde iki farklı özelliğinden bahsedilebilir. İlki çim bitkileri kent dokusu içindeki yapıların çevrelerinde, kent içi ve çevre yollarının şev, banket ve orta refüjlerinde, yaya yollarında, parklar ve piknik alanlarında, hava alanlarında, spor alanlarında olmak üzere kentsel dokuya estetik katkı sağlaması yönünde olup, ikincisi de fonksiyonel anlamda kentsel yaşamı birey refahını artırma yönünde olmaktadır (Küçükerbaş ve ark., 1997). Bu da, toz zerreciklerini adsorbe ederek havanın temizlenmesine katkı yapmak, güneş ışınlarını absorbe ederek ortama serinlik katarak, oyun oynama, eğlence, dinlence amaçlı faaliyetlere imkan tanıyarak yumuşak zemin oluşturmak, toprak kaymasını önleyerek erozyon riski olan yüzeylerde toprağın tutunmasını sağlamak, kütlesel yapılarla uyum içinde sıcak ve canlı bir geçiş özelliğini taşımak gibi çok yönlü işlevler şeklinde kendisini göstermektedir (Küçükerbaş ve ark., 1997). Estetik ve fonksiyonel açıdan kent insanına ideal fiziksel ortam firsatları sunan çim alanların teşekkülü için bu çalışmada aşağıda yer alan sorular kapsamında teorik ve amprik çalışmalara yer verilmiştir.

1. Çanakkale ekolojisi için en elverişli çim türü/türleri hangileri olabilir?

2. Söz konusu çim türleri hangi yetiştirme ortamı/ortamlarında başarılı bir performans sergileyebilir?

3. Tespit edilen çim türü/türleri ve yetiştirme ortamı/ortamları kapsamında oluşturulan çim alan tesisi kent insanının yaşam kalitesine pozitif katkı sağlar mı?

Günümüzde açık-yeşil alan uygulamalarının önemli bir bölümünü teşkil eden çim alan tesisinde gerekli çim türlerinin ve bunun için en uygun yetiştirme ortamını sağlayacak toprak sınıflarının tespit edilmesi bu çalışma kapsamında öne çıkan en temel çalışmalardır. Söz konusu çalışmaların özel sektör ve yerel yönetimlerce önemsenmesi, koruma ve geliştirmeye yönelik stratejiler geliştirme açısından önem teşkil etmektedir. Sonuç olarak, çalışmalar neticesinde belirlenen en uygun çim türü ve ortam alternatifleri ile bölge ekolojisi ve amaç doğrultusunda tesis edilen çim alanların, kentsel yapıya canlı ve sıcak bileşen olarak katkı yapan ve toprak yüzeyini tamamen kaplayan kültürel peyzaj donatıları olarak kent insanının yaşam kalitesi noktasında bir kazanım oluşturması beklenmektedir.

\section{Materyal ve Metot}

\subsection{Materyal}

Çanakkale'de uygulanan çim alan tesisinde yukarıda da bahsedildiği gibi çim karışımında ağırlıklı yer alan üç çim tohumunun yetişebileceği en uygun ortamların tespit edilmesi gerekçesiyle yürütülen çalışma Çanakkale kentsel alanında gerçekleşmiş olup, coğrafi konum itibariyle $40^{\circ} 18^{1} 52^{11}$ Kuzey Paralelleri, $26^{\circ} 38^{1} 32^{11}$ Doğu Meridyenleri koordinatlarında yer almaktadır (Şekil 1). Araştırma, Çanakkale/Lapseki Meslek Yüksekokulu yerleşke alanında yürütülmüş olup, alanda yer alan ve bu çalışma için tesis edilen $1 \mathrm{mx} 1 \mathrm{mx} 0,4 \mathrm{~m}$ boyutlarındaki 12 adet yetiştirme tavası ile bu tavaları dolduran kum, mil ve bahçe toprağından oluşan toprak sınıfları çalışmanın ana materyalini teşkil etmektedir. Ayrıca bölge ekolojisine uygun peyzaj çalışmalarının temel öğelerinden biri olan çim alan tesisinde sıklıkla kullanılan İngiliz çimi, kırmızı yumak ve çayır salkım otu türlerinden oluşan çim tohumları da materyal kapsamında değerlendirilmiştir. Bunun dışında deneme için 
kullanılan alet ve araç-gereç sınıfindan tüm araç-gereçlerde aynı kapsamda ele alınmıştır.

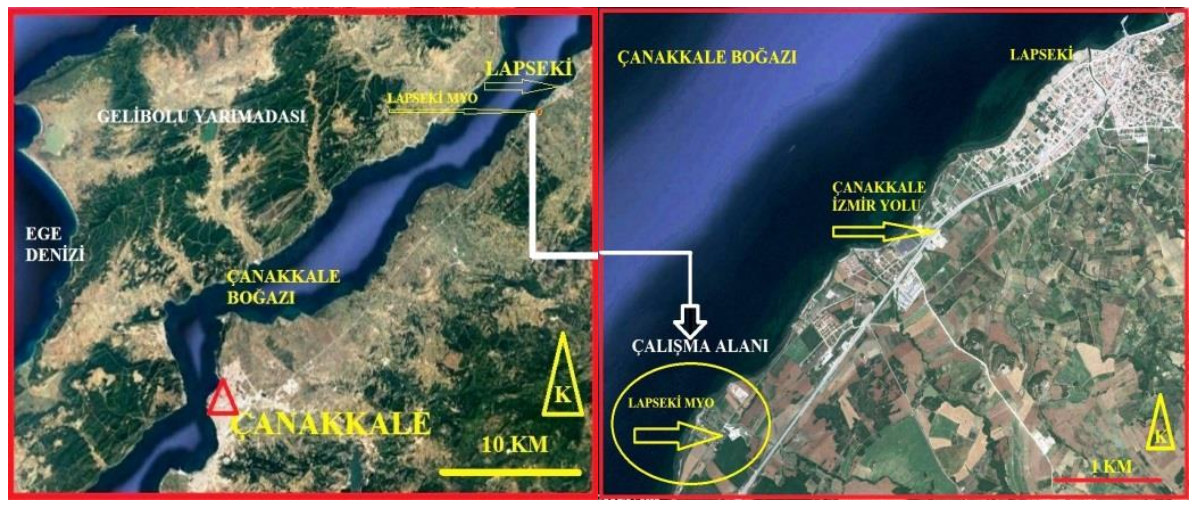

Şekil 1. Çalışma alanı lokalizasyonu (Google Earth'den (2019) uyarlanarak; 20.07.2019)

\subsection{Metot}

Araştırma yöntemi, bulguların elde edilmesi sürecini kapsayan 7 aşamadan oluşmaktadır.

1-Proje başvuru sürecinde başlangıçta belirtilen ve üzerinde çalışılması tasarlanan 4 farklı çim tohumu türünün temini konusunda Türkiye genelinde yapılan araştırma neticesinde, ancak, Ankara Ulusoy Tohumculuk'tan Agrostis tenuis denso (İnce tavus otu) türüne ait tohum haricinde diğer tüm tohumların elde edilmesi geçekleştirilmiş ve çalışma, elde edilen Lolium perenne Topgun (İngiliz Çimi), Festuca rubra Red Skın (Kırmızı Yumak) ve Poa pratensis Avalanche (Çayır Salkım Otu) türlerine ait tohumlar ile başlatılmıştır. 2Toprak sınıflarının (kum, mil, kil) elde edilmesi sürecinde, kil sınıfından toprağın kullanılmasının çok küçük taneli granüler yapısına bağlı olarak sulama işleminde ortaya koyacağı çim tohumlarının köklenmesi ve çimlenmesi üzerine yapacağı olumsuzluklar düşünülerek proje kapsamından çıkarılmasının uygun olabileceği düşünülmüştür. Dolayısıyla çalışmaya kum, mil ve bahçe toprağı sınıflarından bireysel ve karışım olarak elde edilmiş ortamlar kullanılarak başlanmış ve devam edilmiştir. 3-Bu süreçte kürek, tırmık, silindir, çepin, çapa, el arabası, mastar gibi araç-gereç/ekipmanlardan yararlanılmıştır. 4-Çalışmada "Tesadüf Parselleri Deneme Deseni” yöntemi kullanılmıştır (Çelebi ve ark., 2009). Öyle ki, tesadüf parsellerinin (yetiştirme tavası) yapımını kapsayan süreçte, her çim tohumu için 4 farklı parsel (tava) olacak tarzda toplamda 3 çim tohumu için tasarlanan 12 yetiştirme tavasının bitirilmesi proje başvurusunda belirtilen teknik özelliklerde gerçekleştirilmiştir. Yapımı gerçekleşen yetiştirme tavalarından her dördü, bir çim tohumu türüne dört farklı (kum, mil, bahçe toprağı ve bu üç toprak sınıfının eşit karışımı) ortam oluşturacak şekilde tabanlarında yeter miktarda drenaj kanalı ve drenaj dolgusu oluşturularak doldurulmuş ve ekime hazır hale getirilmiştir. $\mathrm{Bu}$ kapsamda bölge için uygun olup yoğun kullanım sergileyen ve çalışmanın örneklemini oluşturan yukarıda bahsi geçen 3 farklı serin iklim çim türüne ait tohumlar ayrı ayrı, içinde kum, mil, bahçe toprağı ve her üçünün eşit karışımı bulunan 4 farklı yetiştirme tavasına/parseline (toplamda 12 adet, $1 \mathrm{mx} 1 \mathrm{mx} 0,3 \mathrm{~m}$ boyutlarındaki betonarme yetiştirme tavası inşa edilmiştir/Şekil 2) ekilmişlerdir. 5-Çim tohumlarının ekimi metrekareye yaklaşık 40-50 gram ölçüsünde ve homojen olarak sağlanmıştır. Daha sonra üst kapak toprağı tohum iriliğinin 1,5-2 katı gibi serilmiş, silindirlenerek sikıştırılmış ve yüzey düzlenmiştir. Böylece tohumların toprakla temas yüzdesi artırılmıştır. Tohumlar kök bağlayıncaya kadar (yaklaşık 1-2 hafta) her gün sabah ve akşam olmak üzere sulama işlemine toprağın doyum noktası ölçü kabul edilerek devam edilmiştir. Köklenmeyle sürgün oluşumundan itibaren de sulama her gün için bir defaya düşürülmüştür.

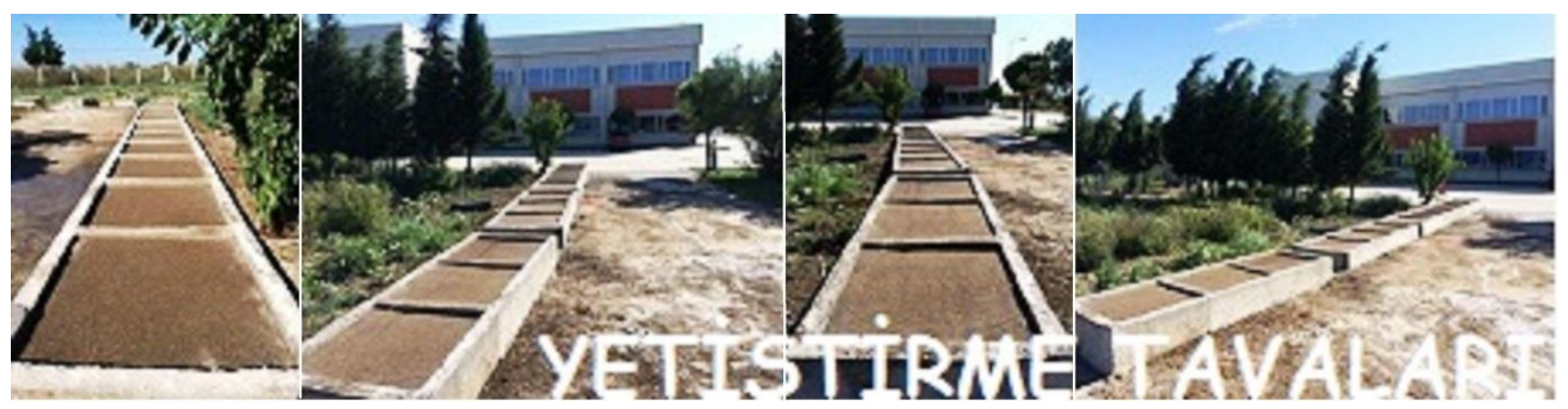

Şekil 2. Çim tohumu türleri için hazırlanan yetiştirme tavaları (06.06.2019) 
6-Verilerin elde edilmesi sürecinde ise, söz konusu çim türlerine ait tohumların ekim işlemlerinden yaklaşık 1-2 haftalık süreçte çıkışlar görülmeye başlanmış ve verilerin alınması aşamasına geçilmiştir. Verilerin alınma süreci yaklaşık 2 ayı bulmuştur. Bu süreçte Tohumların çıkışından başlayarak vegetatif gelişim periyodunca çim türlerinin gösterdikleri performanslar inceleme ve gözleme tabi tutularak değerlendirme ilkeleri (çimlenme, yayılma/yüzey kaplama hızı ve yüzdesi, renk koyuluğu ile doku/tekstür) bakımından elde ettikleri nitelikler, çok $a z$ (1), az (2), fazla (3) ve çok fazla (4) ölçüm skalası doğrultusunda sayısallaştırılmıştır. Her tür için 10 adet veriye bağlı olarak toplamda 120 veri elde edilmiştir.levhalar üretilmiştir. 7-Daha sonra bu veriler tür bazında ortalama ölçüm değerleri şeklinde ele alınarak, (yani her tür için farklı vegetatif gelişim dönemlerinde alınan 10 ölçüm değerinin ortalamaları alınarak) toplamda 12 ölçüm ortalama değeri SPSS 15.0 istatistiki analiz programında yer alan Post-Hoc testi kullanılarak analiz edilmiştir. Analiz sonucunda edinilen bulguların anlamlılık düzeyleri ve birbirleri arasındaki istatistiksel ilişkiler ortaya çıkartılmıştır. Söz konusu istatistiksel ilişkiler ve nitelik karşılaştırmalarına bağlı olarak yapılan ölçüm skalası ile elde edilen sonuçların birbirlerini doğrulaması ve bununla ilişkilendirilerek de kullanılan çim çeşitleri için en uygun ortamın/ortamların belirlenmesi yoluna gidilmiştir.

\section{Bulgular ve Tartışma}

\subsection{Bulgular}

Elde edilen veriler doğrultusunda 3 farklı çim tohumu için birbirine yakın verilere ulaşılmış olup, kum, mil ve bahçe toprağı sınıflarının eşit oranlarda karışımından oluşan parselin her üç tohum için en elverişli ortam olduğu kanaatine varılmıştır. Elde edilen tüm veriler dikkate alındığında mil ağırlıklı parselin tüm tohum türleri için 2. derecede, bahçe toprağı oranı yüksek olan parselin yine tüm tohum türleri için 3. derecede, kum ağırlıklı parselin ise 4.derecede elverişli oldukları sonucuna ulaşılmıştır. Çalışmada, verilerin alınma süreci yaklaşık 2 ayı bulmuştur. Bu süreçte değerlendirme ilkeleri doğrultusunda ölçüm skalasına bağlı olarak her bir tohum türü için gözlem ve incelemeler yapılmıştır. Söz konusu inceleme ve gözlemler sayısallaştırılarak her bir tür için 10 veri elde edilmiştir. Toplamda ulaşılan 120 veri üzerinden çim tohumu türleri için ortalama ölçüm değerlerinden yola çıkarak (örneğin İngiliz çim türü için kum parselinde gösterdiği gelişim performansına (Şekil 3) verilen 10 ölçüm değerinin ortalaması alınarak) elde edilen verileri kapsayan çizelgelere ve her çizelge için öngörülen yorumlara aşağıda yer verilmiştir.

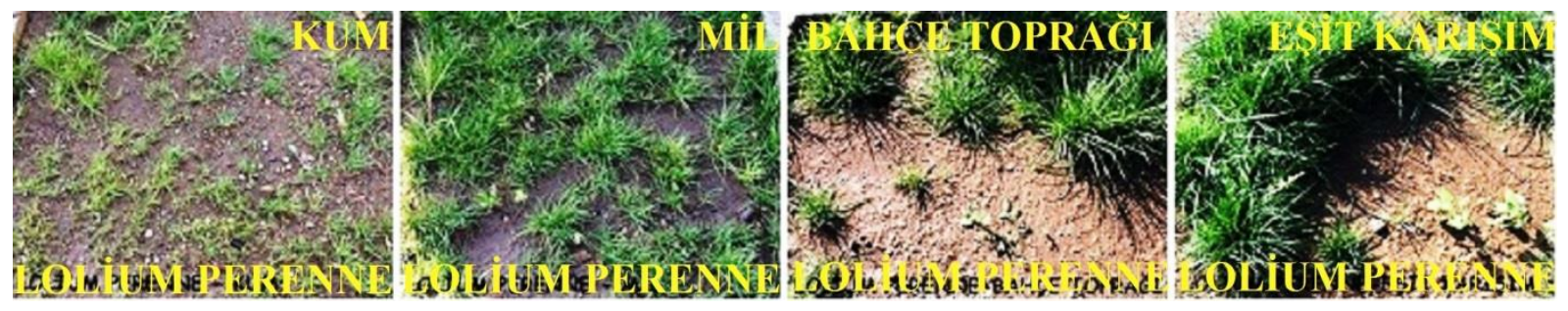

Şekil 3. Lolium perenne Topgun (Ingiliz Çimi) çim tohumunun 4 farklı ortamda gösterdikleri ortalama performanslar

Tablo 1'e göre; kum ağırlıklı ortamda İngiliz çim tohumu, çimlenme hızı, yayılma hızı, renk koyuluğu ve doku yoğunluğu ilkeleri bakımından ortamdaki geçirgen özellikten dolayı su tutma kapasitesinin düşük olması, buna bağlı olarak da nispeten daha çabuk ortamın kuruyarak çim tohumunun susuzlukla karşı karşıya kalması ile beklendiği üzere çok az derecede nitelik ve ilkelere sahip olduğu görülmüştür.

Tablo 1. Lolium perenne Topgun (Ingiliz Çimi) çim tohumunun 4 farklı ortamda gösterdikleri ortalama performanslar

\begin{tabular}{lllll}
\hline Değerlendirme İlkeleri & $\begin{array}{l}\text { Kum } \\
\text { (ortalama) }\end{array}$ & $\begin{array}{l}\text { Mil } \\
\text { (ortalama) }\end{array}$ & $\begin{array}{l}\text { Toprak } \\
\text { (ortalama) }\end{array}$ & $\begin{array}{l}\text { Eşit Karışım (Kum+Mil+Bahçe Toprağı) } \\
\text { (ortalama) }\end{array}$ \\
\hline Çimlenme Hızı & 1 & 3 & 2 & 4 \\
Yayılma/Kaplama Hızı & 1 & 3 & 2 & 4 \\
Renk Koyuluğu & 1 & 4 & 3 & 4 \\
Doku/Tekstür & 1 & 4 & 3 & 4 \\
\hline
\end{tabular}

Ölçüm Skalası: 1:ÇokAz; 2:Az; 3:Fazla; 4: Çok Fazla 
$\mathrm{Bu}$ durum mil ağırlıklı ortamda yerini, çimlenme ve yayılma hızı olarak fazla; yeşil rengin yoğunluğu ve dokusu bakımından ise çok fazla olduğu yönündeki gelişmeye bırakmıştır. Yüksek oranda topraktan oluşan ortam, İngiliz çim tohumu üzerinde çimlenme ve yayılma hızında diğer ortamlara göre az, renk ve doku bakımından ise, fazla gelişme göstermesi üzerine etkili olmuştur. Eşit oranlarda kum, mil ve bahçe toprağının karışımından elde edilen ortamda, İngiliz çiminin belirlenmiş ilkeler kapsamında ve beklentiler doğrultusunda en iyi performansı gösterdiği gözlenmiştir. Sonuç olarak İngiliz çiminin en iyi performansı karışımda gösterdiği, bunu mil ağırlıklı, toprak ağırlıklı ve kum ağırlıklı ortamların izlediği tespit edilmiştir. Şekil 4'ten de anlaşılacağı üzere kırmızı yumak çim tohumu çeşidi için, çimlenme ve yaşam yeteneği açısından en elverişli deneme parselinin, eşit oranlarda kum, mil ve bahçe toprağ 1 karışımından oluşan ortam olduğu söylenebilir. Ulaşılan bu sonuçta söz konusu tohum türünün ekimi ile başlayan süreçte performans belirlemeye yönelik ilkelerden çimlenme hızı, yayılma hızı, renk koyuluğu ve doku yapısı olarak çok fazla (4) derecesinde niteliklere sahip olduğu etkili olmuştur. Mil ağırlıklı ortamın bu çim tohumu türü için hem çimlenme hem de yaşam yeteneği bakımından 2. Dereceden elverişli olduğundan bahsedilebilir.

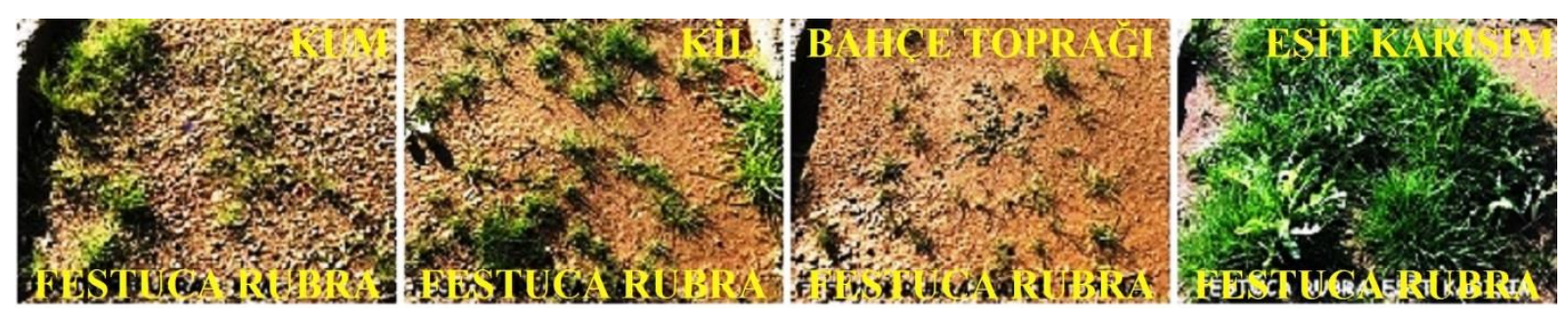

Şekil 4. Festuca rubra Red Skın (Kırmızı Yumak) çim tohumunun 4 farklı ortamda gösterdikleri ortalama performanslar

Genel anlamda performans belirlemeye dönük ilkeler kapsamında söz konusu tohum türü için 3. dereceden yani fazla derecesinde niteliklere sahip olduğu görülmüştür. Renk koyuluğu ve doku özelliği açısından az derecesinde; çimlenme hızı ve yayılma hızı ilkeleri açısından ise çok az derecesinde niteliklere sahip olduğundan da bahçe toprağı ağırlıklı ortamın 3. dereceden elverişli olduğu tespit edilmiştir. Son olarak kum ağırlıklı ortamın doğal yapısından ileri gelen nispeten fazla süzeklik ve kısa sürede kuruma özelliklerinden dolayıdır ki, performans ilkeleri açısından elde edilen sonuçlar bu tohum türü açısından çok az derecesinde kalmıştır. Bu durum kum ağırlıklı ortamı, kırmızı yumak tohum türü için deneme deseninde yer alan parseller içinde elverişlilik bakımından en alt sıraya taşımıştır (Tablo 2).

Tablo 2. Festuca rubra Red Skın (Kırmızı Yumak) çim tohumunun 4 farklı ortamda gösterdikleri ortalama performanslar

\begin{tabular}{lllll}
\hline Değerlendirme İlkeleri & $\begin{array}{l}\text { Kum } \\
\text { (ortalama) }\end{array}$ & $\begin{array}{l}\text { Mil } \\
\text { (ortalama) }\end{array}$ & $\begin{array}{l}\text { Toprak } \\
\text { (ortalama) }\end{array}$ & $\begin{array}{l}\text { Eşit Karışım (Kum+Mil+Bahçe Toprağı) } \\
\text { (ortalama) }\end{array}$ \\
\hline Çimlenme Hızı & 1 & 3 & 1 & 4 \\
Yayılma/Kaplama Hızı & 1 & 3 & 1 & 4 \\
Renk Koyuluğu & 1 & 3 & 2 & 4 \\
Doku/Tekstür & 1 & 3 & 2 & 4 \\
\hline
\end{tabular}

Ölçüm Skalası: 1:Çok Az; 2:Az; 3:Fazla; 4: Çok Fazla

Şekil 5'e göre ise; çayır salkım otu tohumunun, vegetatif gelişim açısından gösterdiği performansa bakıldığında, karışımdan oluşan ortamda çimlenme hızı, yayılma hızı, renk koyuluğu ve doku özelliği bakımından en iyi performansı gösterdiği; kum ağırlıklı ortamda ise en düşük performansı sergilediği gözlenmiştir. Milin yoğunlukta olduğu ortamın bu çim tohumunun çimlenme ve gelişme üzerine olan etkilerine bakıldığında ise, çimlenme ve yayılma hızı üzerine çok fazla derecesinde, renk koyuluğu ve doku yapısı üzerine ise fazla derecesinde etkili olduğu görülmüştür. Bahçe toprağından oluşan parselde ise, ortam özelliğine bağlı olarak çimlenme ve yayılma hızlarının çok az derecesinde olduğu, yani düşük olduğu, az derecesinde olsa da renk koyuluğu ve doku üzerine etkili olduğu gözlenmiştir. 

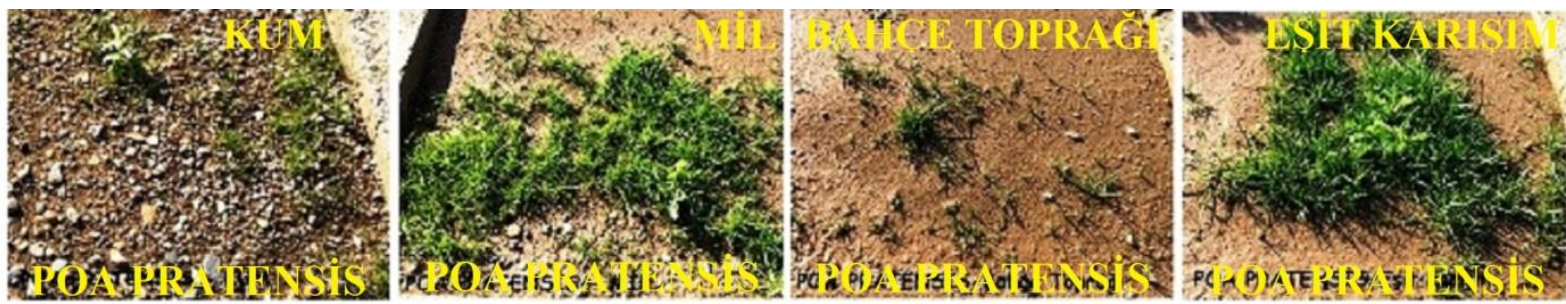

Şekil 5. Poa pratensis Avalanche (Çayır Salkım Otu) çim tohumunun 4 farklı ortamda gösterdikleri ortalama performanslar

$\mathrm{Bu}$ durum, bahçe toprağından oluşan ortamın çayır salkım otu tohumunun köklenmesi ve gelişiminde 3 . derecede etkili/önemli olduğunu ortaya koymaktadır.1. ve 2. sırada ise, bu sırayla eşit karışımı ve milden oluşan parseli söyleyebiliriz. Köklenme ve gelişimde en az derecede etkili olan deneme deseni ise kum parseli olmuştur (Tablo 3).

Tablo 3. Poa pratensis Avalanche (Çayır Salkım Otu) çim tohumunun 4 farklı ortamda gösterdikleri ortalama performanslar

\begin{tabular}{lcccc}
\hline $\begin{array}{l}\text { Değerlendirme } \\
\text { Ilkeleri }\end{array}$ & $\begin{array}{c}\text { Kum } \\
\text { (ortalama) }\end{array}$ & $\begin{array}{c}\text { Mil } \\
\text { (ortalama) }\end{array}$ & $\begin{array}{c}\text { Toprak } \\
\text { (ortalama) }\end{array}$ & $\begin{array}{c}\text { Eşit Karışım (Kum+Mil+Bahçe } \\
\text { Toprağı) (ortalama) }\end{array}$ \\
\hline Çimlenme Hızı & 1 & 4 & 1 & 4 \\
Yayılma/Kaplama & 1 & 4 & 1 & 4 \\
Hızı & 1 & 3 & 2 & 4 \\
Renk Koyuluğu & 1 & 3 & 2 & 4 \\
Doku/Tekstür & 1 & 3 & & \\
\hline
\end{tabular}

Ölçüm Skalası: 1:Çok Az; 2:Az; 3:Fazla; 4: Çok Fazla

Performans analizi için öngörülen süreçte elde edilen veriler değerlendirilmiş ve sonuçlar ortaya konulmaya çalışılmıştır. Buna göre, bölge için çim alanı tesisinde önemli yerleri olduğu gerekçesiyle araştırma kapsamında belirlenmiş olan Lolium perenne topgun (ingiliz çimi), Festuca rubra rubra red skin (kırmızı yumak) ve Poa pratensis avalanche (çayır salkım otu) çim türlerine ait çimlenme ve yaşam yeteneklerinin 4 farklı parselde ortaya koydukları performanslar belirlenmeye çalışılmış, elde edilen veriler doğrultusunda 3 farklı çim türü tohumunun birbirine yakın veriler ortaya koydukları görülmüştür. Hosaflığlu ve Yılmaz'ın da (2017:301-308), çalışmasında, Van koşullarına adaptasyonunun incelendiği çim türlerinin yıllık ve mevsimsel olarak gösterdikleri performans bakımından benzer/yakın sonuçlar verdikleri görülmüştür. Dolayısıyla, beklentilere de paralel olduğu düşünülen kum, mil, toprak karışımından oluşan parselin her üç tohum türü için de en elverişli ortam olduğu kanaatine varılmıştır. Bununla birlikte elde edilen tüm veriler dikkate alındığında mil ağırlıklı parselin tüm tohum türleri için 2. derecede, bahçe toprağı oranı yüksek olan parselin yine tüm tohum türleri için 3. derecede, kum ağırlıklı parselin ise 4.derecede elverişli oldukları sonucuna ulaşılmıştır.

Tablo 4. Çim tohumlarının farklı yetiştirme ortamlarına gösterdikleri performansların betimleyici istatistikleri

\begin{tabular}{llll}
\hline & $\begin{array}{l}\text { Ortalama } \\
\text { (Mean) }\end{array}$ & $\begin{array}{l}\text { Standart Hata } \\
\text { (Std. Deviation) }\end{array}$ & $\mathrm{N}$ \\
\hline Kum & 1,00 &, 000 & 12 \\
Mil & 3,33 &, 492 & 12 \\
Bahçe_Topragi & 1,83 &, 718 & 12 \\
Esit_Karisim_KumMilBahçeTopragi & 4,00 &, 000 & 12 \\
\hline
\end{tabular}

Çim tohumlarının tepkimelerinde belirleyici olan verilerden ortaya çıkan bu bulguları desteklemek amacıyla çalışma ile belirlenmiş söz konusu verilere istatistiksel analiz kapsamında, çim tohumu tepkimelerindeki farklılıkların anlamlı olup olmadığını test etmek amacıyla istatistiksel testlerden Post-Hoc Testi uygulanmıştır. Test sonucunda elde edilen bulgular aşağıda yer almaktadır. Tablo 4'e göre, bahçe toprağı ortalaması $(X=1,83)$ ile kumun ortalaması $(X=1,00)$ arasında, bahçe toprağı lehine; bahçe toprağı ortalaması $(X=1,83)$ ve milin ortalaması $(X=3,33)$ arasında milin lehine; eşit karışım ortalaması olan $(X=4,00)$ ile milin ortalaması $(X=3,33)$ arasında ise, eşit karışım lehine fark olduğu ortaya çıkmıştır. 
Tablo 5. Çim tohumu türlerinin farklı ortamlardaki performansların anlamlılık düzeyleri

\begin{tabular}{lllllll}
\hline Effect & Value & F & $\begin{array}{l}\text { Hypothesis } \\
\text { df }\end{array}$ & $\begin{array}{l}\text { Error } \\
\text { df }\end{array}$ & $\begin{array}{l}\text { Sig. } \\
(\mathrm{P})\end{array}$ \\
\hline Tepkimeler & Pillai's Trace &, 991 & $548,636(\mathrm{a})$ & 2,000 & 10,000 & $\mathbf{, 0 0 0}$ \\
& Wilks' Lambda &, 009 & $548,636(\mathrm{a})$ & 2,000 & 10,000 & $\mathbf{, 0 0 0}$ \\
& Hotelling's Trace & 109,727 & $548,636(\mathrm{a})$ & 2,000 & 10,000 & $\mathbf{, 0 0 0}$ \\
& Roy's Largest & 109,727 & $548,636(\mathrm{a})$ & 2,000 & 10,000 & $\mathbf{, 0 0 0}$ \\
\hline
\end{tabular}

Ayrıca söz konusu çim tohumlarının farklı yetiştirme ortamlarına gösterdikleri tepkimeler arasında genel olarak anlamlı fark olduğu da Tablo 5'te görülmektedir $(\mathrm{P}<0,05)$. Bu bulgular, yukarıda elde edilen inceleme ve gözleme dayalı ölçüm değerlerinden varılan sonuçların teyidi olarak değerlendirilebilir.

Tablo 6. Çim tohumlarının tekerrürlü performansların varyans analizi

\begin{tabular}{lllllll}
\hline Kaynak & Tepkimeler & $\begin{array}{l}\text { Kareler } \\
\text { Toplamı }\end{array}$ & $\begin{array}{l}\text { Serbestlik } \\
\text { Derecesi } \\
(\mathrm{df})\end{array}$ & $\begin{array}{l}\text { Kareler } \\
\text { Ortalaması }\end{array}$ & F & $\begin{array}{l}\text { Sig. } \\
(\mathbf{P})\end{array}$ \\
$\begin{array}{l}\text { Çim Tohumu } \\
\text { Türler Arası }\end{array}$ & Linear & 33,750 & 1 & 33,750 & $\mathbf{1 0 6 0 , 7 1 4}$ & $\mathbf{, 0 0 0}$ \\
\hline
\end{tabular}

Aynı tabloya göre, çim tohumlarının farklı ortamlardan oluşan parsellerde gösterdikleri tepkimelere bakıldığında \% 5 düzeyinde önemli oldukları anlaşılmaktadır. Tablo 6'ya bakıldığında ise, çim tohumu türlerinin tekerrürlü tepkimeleri arasında anlamlı fark olduğu ortaya çıkmıştır. (P<0,05; F: 1060,714).

Tablo 7. Çim tohumlarının performanslarına göre Post-Hoc testi sonuçları

\begin{tabular}{|c|c|c|c|c|c|c|}
\hline \multirow[t]{3}{*}{$\begin{array}{l}\text { (I) } \\
\text { Tepkimeler }\end{array}$} & \multirow[t]{3}{*}{$\begin{array}{l}\text { (J) } \\
\text { Tepkimeler }\end{array}$} & \multirow{3}{*}{\begin{tabular}{l}
\multicolumn{1}{c}{ (I-J) } \\
Ortalamalar \\
Fark1 \\
Lower \\
Bound
\end{tabular}} & \multirow{3}{*}{$\begin{array}{l}\text { Standart } \\
\text { hata } \\
\text { Upper } \\
\text { Bound }\end{array}$} & \multirow{3}{*}{$\begin{array}{l}\text { Anlamlılık } \\
\text { Düzeyi- } \\
\text { Sig.(a)(P) } \\
\text { Lower } \\
\text { Bound }\end{array}$} & \multicolumn{2}{|c|}{$\begin{array}{l}\text { 95\% Confidence Interval } \\
\text { for Difference(a) }\end{array}$} \\
\hline & & & & & Upper & Lower \\
\hline & & & & & Bound & Bound \\
\hline \multirow[t]{3}{*}{1} & 2 & $-2,333(*)$ & ,142 & ,000 & $-2,789$ & $-1,877$ \\
\hline & 3 &,$- 833(*)$ & ,207 & ,012 & $-1,498$ &,- 169 \\
\hline & 4 & $-3,000$ &, 000 & . & $-3,000$ & $-3,000$ \\
\hline \multirow[t]{3}{*}{2} & 1 & $2,333(*)$ & ,142 & ,000 & 1,877 & 2,789 \\
\hline & 3 & $1,500(*)$ & ,230 & ,000 &, 761 & 2,239 \\
\hline & 4 &,$- 667(*)$ & ,142 & ,004 & $-1,123$ &,- 211 \\
\hline \multirow[t]{3}{*}{3} & 1 &, $833(*)$ & ,207 &, 012 & ,169 & 1,498 \\
\hline & 2 & $-1,500(*)$ & ,230 & ,000 & $-2,239$ &,- 761 \\
\hline & 4 & $-2,167(*)$ & ,207 & ,000 & $-2,831$ & $-1,502$ \\
\hline \multirow[t]{3}{*}{4} & 1 & 3,000 & ,000 & . & 3,000 & 3,000 \\
\hline & 2 &, $667(*)$ &, 142 & ,004 & ,211 & 1,123 \\
\hline & 3 & $2,167(*)$ & ,207 & ,000 & 1,502 & 2,831 \\
\hline
\end{tabular}

Bonferroni testi tablosu ile ana etkilerin karşılaştırılması Bonferroni testine göredir. Tahmini marjinal ortalamalara göre; *. Ortalama fark, 0,05 düzeyinde önemlidir. a . Çoklu karşılaştırmalar için ayarlama: Bonferroni.

Tablo 7'ye göre, yapılan Post-Hoc testi sonuçlarına göre, çim tohumlarının yetiştirme ortamlarına gösterdikleri tepkimeler bakımından 1. parsel sabitken 2. ve 3. parseller; 2. parsel sabitken 1., 3. ve 4. parseller; 3. parsel sabitken 1., 2. ve 4. parseller; 4. parsel sabitken 2. ve 3. parseller kendi aralarında anlamlı bir farka sahiptir. Buradan şu yoruma varılabilir. Kum parseli sabit tutulduğunda mil ve bahçe toprağı grubundan oluşan parsellerin aralarında anlamlı ilişkiye sahip olduğu görülmektedir. Aynı şekilde, mil parseli sabitken kum, bahçe toprağı ve eşit karışım parsellerinin aralarında anlamlı, bahçe toprağı sabitken kum, mil ve eşit karışım parsellerinin aralarında anlamlı, son olarak da eşit karışım parseli sabitken mil ve bahçe toprağı parsellerinin aralarında 
anlamlı ilişkiye sahip olduğu tespit edilmiştir.

\subsection{Tartışma}

Çalışmanın ana materyalini teşkil eden parseller, yetiştirme tavaları şeklinde $1 \mathrm{mx} 1 \mathrm{mx} 0,3 \mathrm{~m}$ ebatlarında toplamda 12 adet olacak şekilde hazırlanmıştır. Benzer şekilde Arslan ve Çakmakçı, (2004) çalışmasında $2 \mathrm{mx} 2 \mathrm{~m}$ standartlarında oluşturulan parselleri, Çelebi ve ark., (2009) yaptıkları çalışmada da 1mx2m ebatlarında oluşturdukları parselleri kullanmışlardır. Diğer taraftan, Hosaflığlu ve ark., (2018), yaptıkları çalışmayı tesadüf blokları deneme desenine göre üç tekrarlı olarak yürütmüşlerdir. Keza, Aydınşakir ve ark., (2014), çalışmalarında uyguladıkları söz konusu yöntem bu çalışmada da kullanılmıştır. Peyzaj Mimarlı̆̆ı uygulama çalışmaları kapsamında en temel uygulamalardan birisi olan çim alanı tesisinde özellikle bu bölge için düşünülen çalışmalarda, araştırmada geçen çim tohumu türlerinin karışım halinde veya soliter olarak, araştırmada yer alan eşit karışım (kum, mil ve bahçe toprağı) özelliğindeki parsellerde yapılacak çim alan tesisiyle en doğru ve rasyonel bir uygulama yapılabileceği ortaya çıkmaktadır. Bu sonuç itibariyle Çelebi ve ark., (2009), yaptıkları çalışmada da benzer şekilde çim alan tesisinde hızlı bir yayılma yüzdesi isteniyorsa uygulanacak çim tohumu karışımında yüksek oranda Festuca tohum türünün bulunması gerektiğine vurgu yapmışlardır. Bu çalışmada da denemesi yapılan 3 çim tohumunun karışımından oluşan kombinasyonun çim alan tesisinde kullanılmasıyla çimlenme hızı, yayılma hızı, renk yoğunluğu ve doku özelliğiyle istenilen standartta bir çim alanı tesisi söz konusu olabilecektir. Benzer şekilde, pek çok çalışmada da (Hay, 1985; Alagöz ve Türk, 2017), Poa, Lolium, Festuca ve Agrostis cinslerinden farklı varyetelerin değişik oranlarda karıştırılması ile oluşturulacak karışımlarla farklı amaçlar için kurulacak çim alanlarda daha etkili sonuçlar alınabileceğine dikkat çekilmiştir. Verilerin elde edilmesi sürecinde ise, söz konusu çim türlerine ait tohumların ekim işlemlerinden yaklaşık 1-2 haftalık kısa bir süreçte çıkışlar görülmeye başlanmış ve verilerin alınması aşamasına geçilmiştir. Aslan ve Çakmakçı, (2004), yaptıkları çalışmada da benzer şekilde ekimden 15 gün sonra denemede yer alan tüm çim tohumlarını çoğunun tüm tekerrürlerinde çıkışlar gerçekleşmiştir. Çok yıllık çimlerde bu çalışmada da olduğu gibi çimlenme hızı, kaplama yüzdesi ve yayılma hızları bakımında diğer çim türlerine kıyasla daha fazla performans sergiledikleri görülmüştür (Harkess, 1970; Petersen, 1991; Hubbard, 1992; Avcıŏlu, 1997; Oral ve Açıkgöz, 1999; Zorer ve Andiç 2003). Açıkgöz (1994), çok yıllık çimlerin, yumak türlerinin ve salkım otunun bu sirayla düşüktenyükseğe doğru çimlenme hızına sahip olduklarını belirtmiş̧tir. Petersen (1991), yaptı̆̆ı çalışmada yine çimlenme hızı bakımında diğer çim türlerine kıyasla $\mathrm{L}$. perenne ve $\mathrm{F}$. arundinacea'nin daha iyi sonuç verdiğini belirtmektedir. Arslan (2010) da L. perenne'nin yer aldığı karışımlarda çıkış hızı bakımından benzer sonuca ulaşmıştır. Ayrıca, bu çalışma, Hosaflıoğlu ve ark., (2018) ile Arslan ve Çakmakçı (2004) çalışmalarıyla, çimlenme hızı, kaplama yüzdesi ve renk özellikleri bakımından örtüşmekte olup, çiğnenmeye karşı tepkileri, bitki boyu, yaş ot verimi ve yaprak eni bakımından örtüşmemektedir. Çalışma kapsamında uygulanan İstatistiksel analiz yöntemi ve elde edilen sonuçlar çerçevesinde bu çalışmayla, benzer yöntemi kullanan çalışmalardan elde edilen sonuçlar karşılaştırılmıştır. Aşağıda bu karşılaştırmaya dair açıklamalar yer almaktadır. Bu çalışmada uygulanan Post-Hoc İstatistiksel Analiz Testi sonucunda elde edilen veriler doğrultusunda çalışmada kullanılan çim tohumu türlerinin farklı ortamlara gösterdikleri tepkimeler arasında $\% 5(\mathrm{P}<0,05)$ düzeyde anlamlı farklılıklar olduğu tespit edilmiştir. Benzer şekilde, Duncan Testini uygulayan Hosaflığlu ve Yılmaz (2017), tesadüf parselleri deneme desenli çalışmalarında, toplamda 15 çim tohumu çeşidi kullanmışlardır. Çeşitler arasında kaplama derecesi bakımından \%1 $(\mathrm{p}<0.01)$ düzeyde çok önemli farklılıklar bulmuşlardır. Arslan ve Çakmakçı, (2004) ise çalışmasında Duncan Testini uygulayarak aynı biçim seviyesine gelmiş türlerin performanslarını analiz etmişlerdir. Sonuç olarak, çalışmada \%1 $(\mathrm{P}<0,01)$ önem düzeyinde 60.63 ortalama ile kullandığı Bermuda çim türünün en iyi değere sahip olduğu bulunmuştur. Ayrıca, aynı analiz sonuçlarına göre tekerrürler arasındaki çim türlerinin performans ortalamaları arasındaki farkın da \%1 seviyesinde önemli olduğu görülmüştür. Alagöz ve Türk, (2017) çalışmasında ise varyans analizi sonucunda ele alınan ilkeler doğrultusunda çim türleri ve arasındaki ilişkilerin\% 1 önem düzeyinde istatistiksel olarak anlamlı bulunmuştur.

\section{Sonuç ve Öneriler}

Bölge ekolojisine göre, çim alan tesisine en uygun tür/türlerin ve yetişme ortamlarının tespitine yönelik yapılan bu çalışmada, çalışmanın materyalini teşkil eden 3 çim tohum türünün fiziksel ve fizyolojik (gelişim) özelliklerinin belirlenmesi aşamasında birbirinden farklı özellikleri ortaya çıkmıştır (Şekil 6). Söz konusu şekildeki verilerden de anlaşılacağı üzere, elde edilen çalışma sonuçlarına göre, çim tesis edilecek alanın hızla ve istenilen tekstüre sahip olması için alanın çim bitkisi ile kaplanmasının istendiği durumlarda kullanılacak tohum karışımının eşit oranlarda Lolium, Festuca ve Poa türlerini ihtiva etmesi ve 1. Derecede uygunluğu tespit edilen eşit karışım (kum+mil+bahçe toprağı) ortamının kullanılmasının önemli olduğu sonucuna varılmıştır. Söz konusu şekildeki verilerden de anlaşılacağı üzere, elde edilen çalışma sonuçlarına göre, çim tesis edilecek alanın hızla ve istenilen tekstüre sahip olması için alanın çim bitkisi ile kaplanmasının istendiği durumlarda 
kullanılacak tohum karışımının eşit oranlarda Lolium, Festuca ve Poa türlerini ihtiva etmesi ve 1. Derecede uygunluğu tespit edilen eşit karışım (kum+mil+bahçe toprağı) ortamının kullanılmasının önemli olduğu sonucuna varılmıştır. 2. derecede mil, 3. derecede ise bahçe toprağı sınıfindan oluşacak ortamın uygun olacağ1 da dikkat çekmektedir. Zira her üç çim türüne ait tohum türlerinin tepkimeleri, eş zamanlı olarak kum, mil ve bahçe toprağından oluşan eşit karışım tavasında çimlenme, yayılma, renk ve doku ilkeleri kapsamında en iyi sonucu vermişlerdir. Bunu, mil ve toprak sınıfından oluşan tavalar (parseller) izlemiştir. Bu sonuçlardan da anlaşılacağı üzere, Çanakkale lokalizasyonunda kültürel peyzajın uygun donatılarından olan çim alan tesisinde ağırlıklı kullanılan İngiliz çimi, kırmızı yumak ve çayır salkım otu tohumlarından her birinin birinci derecede kum, mil ve bahçe toprağının eşit karışımlı tekstüründe en iyi performansı sergilediği ortaya çıkmıştır. Bu uygulamayla, kentsel dokuda daha verimli ve fonksiyonel bir çim alan tesisi söz konusu olabilecektir. Bu kazanıma bağlı olarak kentsel peyzaj kalitesindeki olası artış ile birlikte bireyin kentsel refahının artışı da söz konusu olabilecektir.

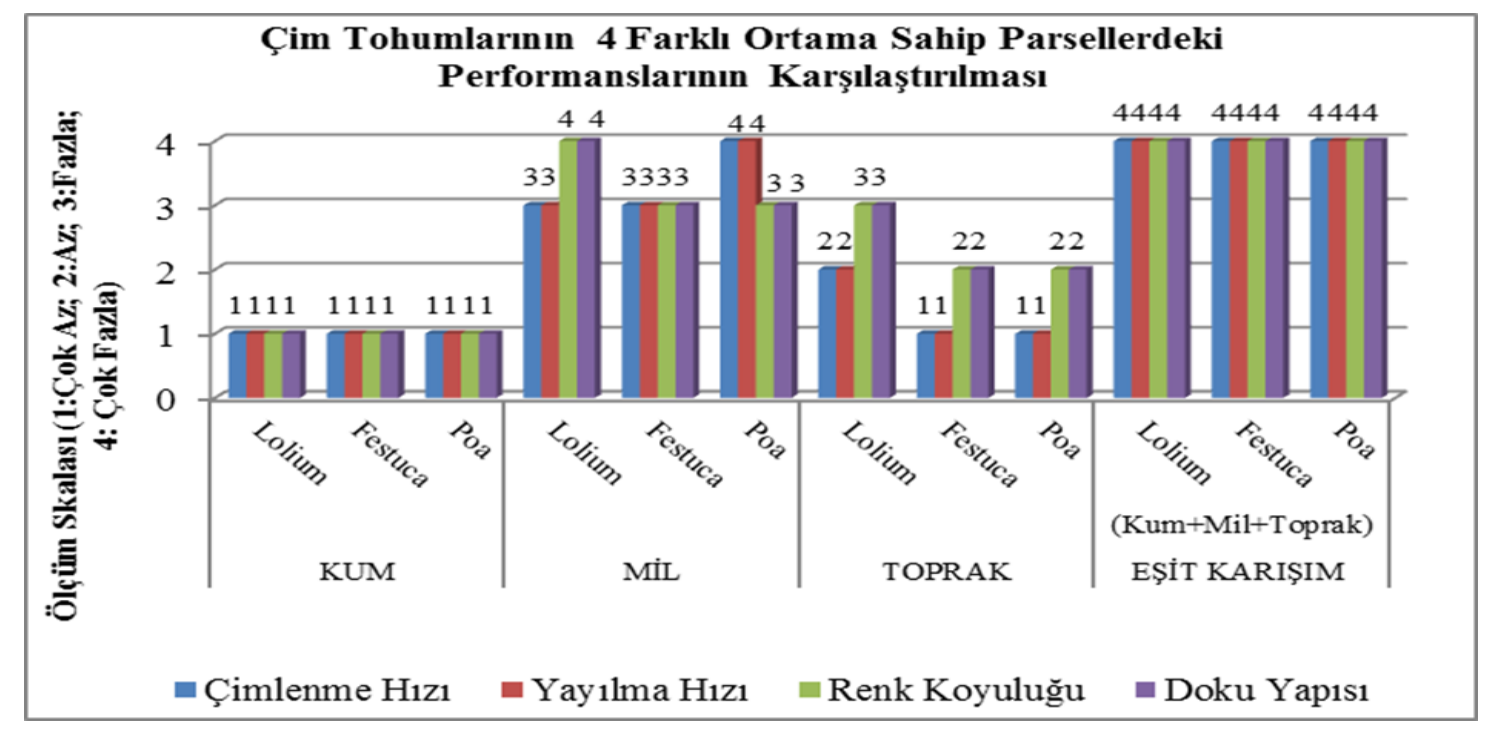

Şekil 6. Çalışma için öngörülen 3 çim tohumunun 4 farklı ortamda gösterdikleri performanslar

\section{Öneriler}

Bölge ekolojisine uygun çim alan tesisinde İngiliz çimi, Kırmızı yumak ve Çayır salkım otu çim tohumlarının eşit oranlı kombinasyonları bu çalışma ile öne çıkmıştır. Söz konusu çim türleri özelinde en uygun toprak sınıfları olarak da kum, mil ve bahçe toprağının eşit oranlarda karışımından oluşan materyal tespit edilmiştir. Kültürel peyzaj planlama ve tasarımlarında adı geçen çim kombinasyonu ile karışım ortamı öncelikli olarak düşünülebilir ve uygulamalarda yer verilebilir. Böylece, çim alan tesisinin daha uzun vadede, daha fonksiyonel ve estetik yönüyle kültürel peyzaja katmadeğer sağlayacağı mümkün olabilecektir. Çim alan tesisinin bu yönüyle değişim ve gelişim adına kente kazandırabileceği katkılar ile kent insanının yaşam standartlarında da gelişmeler sağlayabilecektir.

\section{Teşekkür}

Hazırlanan bu çalışma, Çanakkale Onsekiz Mart Üniversitesi Bilimsel Araştırma Projeleri Komisyonu tarafından FBA-2018-1407 no'lu proje ile desteklenmiştir. Bunun için Çanakkale Onsekiz Mart Üniversitesi - Bilimsel Araştırma Projeleri Koordinasyon Birimi’ne teşekkür ederiz.

\section{Kaynaklar}

1. Alvur, F. (2001). Yönlendirilmiş Yonga levhaların Üretimi, Özellikleri ve Kullanım Yerleri Üzerine Araştırmalar (yayınlanmamış), İÜ Fen Bilimleri Enstitüsü, Orman Endüstri Mühendisliği ABD, İstanbul.

2. Açıkgöz, E. (1994). Çim Alanlar Yapım ve Bakım Tekniği, Uludağ Üniversitesi Ziraat Fakültesi, Bursa.

3. Akdeniz, H., Hosaflioğlu, İ., Keskin, B., (2018). Farklı tohum oranları ve biçim zamanlarının çayır salkım otunun (poa pratensis 1. geronimo) kalite özellikleri üzerine etkileri. Iğdır Üniversitesi Fen Bilimleri Enstitüsü Dergisi, 8(1), 301-308. 
4. Alagöz. M, Türk, M. (2017). Isparta Ekolojik Koşullarında Bazı Buğdaygil Çim Bitkileri ve Karışımlarının Çim Alan Performanslarının Belirlenmesi, SDÜ Ziraat Fakültesi Dergisi, 12, 30-39.

5. Alkan, Y., Sağlık, A., Kelkit A. (2016). Site Yerleşimlerinde Dış Mekân - Peyzaj Niteliğinin Ölçülmesi Ve Konut Değerlerine Etkisi Üzerine Bir Araştırma: Çanakkale Kenti Örneği. Uluslararası Hakemli Tasarım ve Mimarlık Dergisi, 9, 111-128.

6. Alkan, Y., Uslu, C. (2016). Aktif Yeşil Alanların Konut Fiyatları Üzerine Etkisinin Araştırılması: Mersin İli Yenişehir İlçesi Örneği, İnönü Üniversitesi Sanat ve Tasarım Dergisi, 6(13), 1-10.

7. Alkan, Y., Uzun, G. (2016). Erdemli Kenti Mücavir Alanı İçinde Ekolojik Kapsamlı Alan Kullanımı Üzerine Bir Araştırma. Akademik Ziraat Dergisi, 5(1), 35-50.

8. Arslan, D. (2010). Tekirdağ Sahil Kuşağında Bazı Buğdaygil Çim Bitkileri ve Karışımlarının Yeşil Alan Performanslarının Belirlenmesi, Namık Kemal Üniversitesi Fen Bilimleri Enstitüsü, Y. L. Tezi, Tekirdağ.

9. Arslan, M., Çakmakçı, S. (2004). Farklı Çim Tür ve Çeşitlerinin Antalya İli Sahil Koşullarında Adaptasyon Yeteneklerinin ve Performanslarının Belirlenmesi. Akdeniz Üniversitesi Ziraat Fakültesi Dergisi, 17(1), 31-42.

10. Avcıŏ̆lu, R. (1997). Çim Tekniği, Yeşil Alanların Ekimi, Dikimi ve Bakımı. Ege Üniversitesi Ziraat Fakültesi, Tarla Bitkileri Anabilim Dalı, s:271, Bornova-İzmir,

11. Aydinşakir, K., Gürbüz, E., Karagüzel, Ö., Kaya, A.,S. (2014). Kısıntılı Sulamanın Çim Kalitesi Üzerine Etkileri. Araştırma Makalesi/Research Article, Derim, 31 (2), 23-36.

12. Çelebi, Ş.Z., Andiç, N., Yilmaz, İ.H. (2009). Van Bölgesinde Tesis Edilecek Çim Alanları Için Uygun Tür Karışımlarının Saptanması. Yüzüncü Yll Üniversitesi Tarım Bilimleri Dergisi, 19 (2), 91-101.

13. Demirel, K., Yıldırım, M., Çamoğlu, G. (2006). Çanakkale İli Belediye Sınırları İçerisindeki Peyzaj Alanlarında Sulama Sistemlerinin Projelenmesi Ve İşletilmesindeki Hatalar. Atatürk Üniversitesi Ziraat Fakültesi Dergisi, 37(1), 81-90.

14. Gül, A., Küçük, V. (2001). Kentsel Açık - Yesil Alanlar ve Isparta Kenti Örneginde İrdelenmesi. Süleyman Demirel Üniversitesi Orman Fakültesi Dergisi, A(2), 27-48.

15. Hay, R. (1985). The Gardening Year. The Reader's Digest Association Ltd. London, P. 38-40.

16. Hosaflığlu, İ., Yılmaz, İ.H. (2017). Bazı Serin Iklim Bitkilerinin Çim Kaliteleri Ve Kaplama Derecelerinin Belirlenmesi. Ĭgdır Üniversitesi Fen Bilimleri Enstitüsü Dergisi, 7(1), 301-308.

17. Hubbard, C.E. (1992). Grasses, Penguin Books, London, England, 450 p.

18. Küçükerbaş, E., Özkan, B., Kaplan, A., Aslan, N.B. (1997). Lipya çimi (Phyla Nodiflora L.) Bitkisinin İzmir Koşullarında Optimum Su Gereksinimi Ile Basılmaya Dayanımının Saptanması Üzerine Araştırmalar. Turkish Journal of Agriculture And Forestry, 21, 469-474.

19. Oral, N., Açıkgöz, E. (1999). Bursa Bölgesinde Tesis Edilecek Çim Alanları İçin Tohum Karışımları, Ekim Oranları ve Azotlu Gübre Uygulamaları Üzerinde Araştırmalar. Türkiye 3. Tarla Bitkileri Kongresi Bildirileri, 155-159, 15-18 Kasim, Adana.

20. Orçun, E. (1969). Özel Bahçe Mimarisi: Çim Sahaları Tesis ve Bakım Tekniği. Ege Üniversitesi Yayınları Ziraat Fakültesi, Yayın No:152: 106, İzmir.

21. Özbılen, A. (1991). Kent İçi Açık Alanlar, Dağılımı, Tarihi Eserler ve Yeni Yapılaşma: Trabzon Kenti'nde Bir Uygulama Örneği. Karadeniz Teknik Üniversitesi Orman Fakültesi Yayınları, Genel Yayın No:155: 24-26, F.Y.N: 17, Trabzon.

22. Petersen, M. (1991). Management of Turfand Football Fields. DLF Trifolium, Roskilde, Denmark.

23. Sağlık, A., Alkan, Y., Kelkit, A., Çavuşoğlu, G., Sağlık, E. (2016). Peyzaj Mimarlığında Fonksiyonel Mekan Çözümlemesine Yönelik Bir Tasarım Çalışması, Uluslararası Hakemli Tasarım ve Mimarlık Dergisi, (9), 97-110.

24. Sağlık, A., Alkan, Y., Kelkit, A., Devecioğlu, N.E., Sağlık, E. (2016). Meydanların Kent Kimliği Üzerine Etkileri: Çanakkale İskele Meydanı, Uluslararası Hakemli Tasarım ve Mimarlık Dergisi, (7), 112.

25. Harkess, R.D. (1970). Competition Between Tall Fescue and Perennial Ryegrass in Pureand Mixed Swards Under Simulated Field Condition, Journal of Applied Ecology, 52, 497-506 p.

26. Watschke, T.L., Schmıdt, R.E. (1992). Ecological Aspects of Turf Communities, Turfgrass American Society of Agronomy, Inc. Agronomy, 32, 129-174.

27. Zorer, Ş., Andıç, N. (2003). Van Bölgesinde Tesis Edilecek Çim Alanları İçin Uygun Tür Karışımları ve Ekim Oranlarının Saptanması, (Doktora Tezi), Yüzüncü Yıl Üniversitesi, Fen Bilimleri Enstitüsü, Tarla Bitkileri Anabilim Dalı.

28. URL-1. http://www.unicef.org.tr/files/bilgimerkezi/doc/cocuk-istismari-raporu-tr.pdf. (29.06.2019).

29. URL-2. http://biruni.tuik.gov.tr/medas/?kn=204\&locale=tr (29.06.2019).

30. URL-3. http://www.resmigazete.gov.tr/eskiler/2017/07/20170703-8.htm (29.06.2019).

31. URL-4. http://www.mevzuat.gov.tr/Metin.Aspx?MevzuatKod=7.5.19788\&Mevzuatlliski=0\&sourceXmlSearcmekan (29.06.2019). 